\title{
Quality Comparison of Activated Carbon Produced From Oil Palm Fronds by Chemical Activation Using Sodium Carbonate versus Sodium Chloride ${ }^{1}$
}

\author{
Seri MAULINA $\mathbb{D}^{2,3,4, \dagger} \cdot$ Gewa HANDIKA ${ }^{2} \cdot \operatorname{Irvan}^{2,3} \cdot$ Apri Heri ISWANTO ${ }^{4}$
}

\begin{abstract}
Using $\mathrm{Na}_{2} \mathrm{CO}_{3}$ versus $\mathrm{NaCl}$ as chemical activator, we compared the quality of activated carbon produced from oil palm fronds as raw material. These activators were selected for comparison because both are readily available and are environmentally friendly. In the manufacturing, we used Indonesian National Standard (SNI 06-3730-1995) parameters. For the quality comparison, we determined activated-carbon yield, moisture, ash, volatiles, and fixed-carbon contents; and adsorption capacity of iodine. The best characteristics, assessed by morphological surface analysis and Fourier transform infrared (FTIR) spectral analysis, were observed in the carbon activated by $\mathrm{Na}_{2} \mathrm{CO}_{3}$ at an activator concentration of $10 \%$ and carbonization temperature of $400{ }^{\circ} \mathrm{C}$. The results were as follows: activated-carbon yield, $84 \%$; water content, $8.80 \%$; ash content, $2.20 \%$; volatiles content, $14.80 \%$; fixed-carbon content, $68.60 \%$; and adsorption capacity of iodine, $888.51 \mathrm{mg} / \mathrm{g}$. Identification using the FTIR spectrophotometer showed the presence of the functional groups $\mathrm{O}-\mathrm{H}, \mathrm{C}=\mathrm{O}$, $\mathrm{C}=\mathrm{C}, \mathrm{C}-\mathrm{C}$, and $\mathrm{C}-\mathrm{H}$ in the $\mathrm{Na}_{2} \mathrm{CO}_{3}$-activated carbon.
\end{abstract}

Keywords: activated carbon, oil palm fronds, sodium carbonate, sodium chloride

\section{INTRODUCTION}

Oil palm plantation is considered a well-known tropical plantation in Southeast Asia for the past two decades. This vegetative plant plays a major role in various strategic industrial projects as it can increase national income in various important sectors in palm oil-producing countries, such as Indonesia, Malaysia, and Thailand (Irvan et al., 2018). As stated by Prabuningrum et al. (2020) increasing the area and production of oil palm has an impact on increasing the waste from these plants when they are no longer productive at the age of more than 25 years. Palm oil produces 22-palm fronds per-year with an average weight of $2.20 \mathrm{~kg}$ fronds for each palm frond. These figures show the enormous potential of oil palm fronds. Due to large amounts of oil palm frond a produce in palm oil plantation, the selling price of oil palm fronds activated carbon can be reduced to a minimum. Besides, the sustainability of oil palm

\footnotetext{
${ }^{1}$ Date Received April 21, 2020, Date Accepted June 3, 2020

${ }^{2}$ Department of Chemical Engineering, Universitas Sumatera Utara, Jalan Almamater Kampus USU, Medan 20155, Indonesia

${ }^{3}$ Centre of Excellence in Sustainable Energy and Biomaterials, Universitas Sumatera Utara, Medan

${ }^{4}$ Department of Forest Product, Faculty of Forestry, Universitas Sumatera Utara, Padang Bulan, Medan 20155, Indonesia

$\dagger$ Corresponding author: Seri Maulina (e-mail: maulina_harahap@yahoo.com, ORCID: 0000-0002-5856-3768)
} 
fronds activated carbon production can be maintained. However, the utilization of oil palm fronds is still constrained by low levels of digestibility due to high levels of neutral detergent fiber and lignin (Hamchara et al., 2018).

Oil palm fronds fall into the category of wet by-products, approximately contain $70-75 \%$ of water content (Pambayun et al., 2013; Ramdja et al., 2008) with production of oil palm frond approximating 5500 $\mathrm{kg} / \mathrm{ha} /$ years (Hamchara et al., 2018). The availability of palm oil and its waste is abundant. This potential can be utilized by using palm oil waste as an alternative material in carbon manufacturing. This idea resulted in the creation of new economic value, thereby reducing palm oil waste. The above background leads to the importance of conducting research on the manufacture and characterization of activated carbon from oil palm fronds with $\mathrm{Na}_{2} \mathrm{CO}_{3}$ and $\mathrm{NaCl}$ as activators based on activated carbon quality standards according to SNI 06-3730-1995. The reason for choosing these activators because still a few researchers using $\mathrm{Na}_{2} \mathrm{CO}_{3}$ and $\mathrm{NaCl}$ as activating agents in the manufacture of activated carbon especially based on oil palm frond, besides, being easy to obtain, low price and environment friendly.

Activated carbon is an amorphous carbon that possesses a surface area ranging from 1000 to $1500 \mathrm{~m}^{2} / \mathrm{g}$ and has been treated with steam and heat (Rahman et al., 2018). This treatment allows activated carbon to exhibit very strong affinity to absorb various materials with large capability, that is, $25-100 \%$ of activated carbon weight. This affinity relates to the internal pore structure, causing the activated carbon to act as an adsorbent. Activated carbons show selective adsorption properties that depend on the size or volume of the pores and surface area.

Activated carbon shows a wide range of utilization, in the food and drug industry, petroleum chemical industry, water purifier, shrimp cultivation, sugar in-

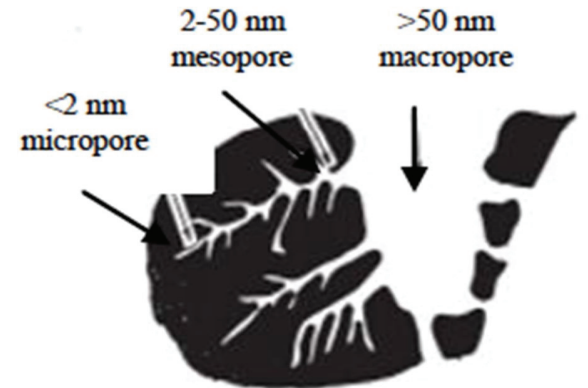

Fig. 1. Schematic of active carbon pore structure.

dustry, gas purification, catalyst, and fertilizer processing (Rahman et al., 2018). Activated carbon possesses a porous surface structure, which is classified by IUPAC as microporous, mesoporous, and macroporous. Fig. 1 shows a schematic of the active carbon pore structure.

Activated carbon is manufactured via two processes, namely, carbonization and activation. The activation process consists of two types, namely, physical activation and chemical activation. Physical activation by gas generally uses $\mathrm{N}_{2}, \mathrm{CO}_{2}$, and water vapor. On the other hand, chemical activation involves an activating agent that is generally a hydroxide $(\mathrm{KOH}$ or $\mathrm{NaOH})$, $\mathrm{ZnCl}_{2}$, and $\mathrm{H}_{3} \mathrm{PO}_{4}$. Oil palm frond is expected to be a source of a raw material to produce activated carbon, besides coconut shells.Lignocellulosic material in oil palm fronds consist of $34.89 \%$ cellulose, $21.54 \%$ hemicellulose, 19.87\% lignin (Maulina et al., 2018). Ash content in a charcoal as raw material was around 10-18\% (Maulina and Anwari, 2019). Hong et al. (2012) stated that ash content of oil palm fronds approximately $12.30 \%$.

\section{MATERIALS and METHODS}

\subsection{Materials}

The materials used in this study included of oil palm fronds, $\mathrm{Na}_{2} \mathrm{CO}_{3}, \mathrm{NaCl}$, distilled water, iodine sol- 
Quality Comparison of Activated Carbon Produced From Oil Palm Fronds by Chemical Activation Using Sodium Carbonate versus Sodium Chloride

ution, sodium thiosulfate, and starch indicator.

\subsection{Equipment}

The equipment used in this research included of furnace, digital balance, 32-mesh screen, porcelain cup, oven, $\mathrm{pH}$ meter, stopwatch, stir bar, tube jar, beaker glass, burette, dropper drop, thermometer, hot plate and magnetic stirrer, desiccator, Whatman filter paper, Fourier transform infrared spectrophotometer (FTIRShimadzu), and scanning electron microscope (SEM Evo MA 10 ZEISS).

\subsection{Methods}

Manufacturing of activated carbon is achieved through several processed from oil palm fronds: preparation, impregnation, carbonization, and analysis performance of activated carbon as a product.

Oil palm fronds were made into chips, oven-dried at $110{ }^{\circ} \mathrm{C}$ for 24 for hours, smoothed with a ball mill, and filtered using a 32-mesh sieve. Impregnation was done at $80^{\circ} \mathrm{C}$ for 2 hours, soaking at room temperature for 24 hours, using activator $5 \%, 7.5 \%$, and $10 \%$ of $\mathrm{Na}_{2} \mathrm{CO}_{3}$ and $\mathrm{NaCl}$. After impregnation, carbonization was conducted for $60 \mathrm{~min}$ at $400{ }^{\circ} \mathrm{C}, 500{ }^{\circ} \mathrm{C}$, and 600 ${ }^{\circ} \mathrm{C}$ to produce activated carbon. The activated carbon

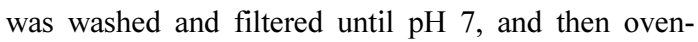
dried. Analysis of products included of yield, moisture content, ash content, volatile matter content, fixed carbon content, and absorption capacity of iodine (Iodine number).

- Yield of activated carbon $\left(\mathrm{Y}_{\mathrm{ac}}\right)$ aims to determine the amount of activated carbon produced after carbonisation and the activation process.

$\mathbf{Y}_{\mathrm{ac}}=\left(\mathrm{W}_{\mathrm{ac}} / \mathrm{W}_{\mathrm{opf}}\right) \times \mathbf{1 0 0 \%}$

Remark: $\mathrm{W}_{\mathrm{ac}}$ : weight of activated carbon, $\mathrm{W}_{\mathrm{opf}}$ : weight of oil palm fronds

- Moisture content (MC) is the amount of water contained in activated carbon.

$$
\begin{aligned}
& \mathbf{M C}=\left[\left(\mathbf{W}_{\mathbf{0}}-\mathbf{W}_{\mathbf{1}}\right) / \mathbf{W}_{\mathbf{0}}\right] \times \mathbf{1 0 0 \%} \\
& \text { Remark: } \\
& \mathrm{W}_{0}=\text { Initial weight; } \\
& \mathrm{W}_{1}=\text { After ovendry weight; }
\end{aligned}
$$

\section{- Ash content $=($ ash weight $/$ initial weight $) \times$} $100 \%$

- Volatile matter content $(\mathrm{VM})$ is volatile content $\mathrm{VM}=\left[\left(\mathrm{W}_{2}-\mathrm{W}_{3}\right) /\left(\mathrm{W}_{2}-\mathrm{W}_{1}\right)\right] \times \mathbf{1 0 0 \%}$

Remark:

$\mathrm{W}_{1}=$ empty crucible weight + cover;

$\mathrm{W}_{2}=$ empty + sample + cover;

$\mathrm{W}_{3}=$ empty crucible weight + residue + cover

- Fixed carbon content is the remaining carbon after carbonisation process and the activation process.

$\%$ Fixed carbon $=100 \%$ - (\%volatile matter content - \%ash content)

- Absorption capacity of iodine (Iodine number) Iodine number is the mass of iodine in grams that is consumed by grams of chemical substances. Iodine number $\left.(\mathrm{mg} / \mathrm{g})=\mathbf{1 0}\left[\left(\mathrm{V}_{\mathrm{b}}-\mathrm{V}_{\mathrm{t}}\right) / \mathrm{W}_{2}\right)\right] \times \mathrm{W}_{1}$ $\times \mathbf{F}_{\mathrm{p}}$

Remark: $\mathrm{V}_{\mathrm{b}}$ : volume of blank titration; $\mathrm{V}_{\mathrm{t}}$ : volume of sample titration; $\mathrm{W}_{1}: 12.693 \mathrm{mg} / \mathrm{ml} ; \mathrm{W}_{2}$ : sample weight $(\mathrm{g})$; and $\mathrm{F}_{\mathrm{p}}$ : dilution factor

Morphological analysis of activated carbon surfaces by using Scanning Electron Microscopy (SEM) with SEM micrographs magnification at 1000x. Fourier Transform Infrared (FTIR) was used to analyze functional groups of activated carbon. The spectra recorded in 45 scans per sample with spectrum range 4000 $400 \mathrm{~cm}^{-1}$ and the resolution of $8.00 \mathrm{~cm}^{-1}$.

\section{RESULTS and DISCUSSION}

This study analyzed a yield of activated carbon and a number of characteristics of activated carbon, including the following: water content, ash content, volatile matter content, fixed carbon content, and iodine 
number. Sodium carbonate and sodium chloride activation mechanisms are:

- $\mathrm{Na}_{2} \mathrm{CO}_{3}+2 \mathrm{C} \rightarrow 3 \mathrm{CO}+2 \mathrm{Na}$, The presence of sodiumin the char leads to the oxidation of cross linking carbon atoms and form into slightly wrinkled or folded or puckered form.

- $\mathrm{NaCl}+2 \mathrm{n} \mathrm{H}_{2} \mathrm{O} \rightarrow \mathrm{Na}^{+}\left(\mathrm{H}_{2} \mathrm{O}\right)_{\mathrm{n}}+\mathrm{Cl}^{-}\left(\mathrm{H}_{2} \mathrm{O}\right)_{\mathrm{n}}$, these molecules will be trapped in cellulose and cellulose become swelling.

\subsection{Yield of activated carbon}

Yield of activated carbon was measured after carbonization and oven dry step. Fig. 2 reveals the yield of activated carbon obtained by activation at various temperatures and concentrations.

A total of $63.33-74.00 \%$ of activated carbon yield was produced using $\mathrm{Na}_{2} \mathrm{CO}_{3}$ activator, whereas 66.67$88.67 \%$ of activated carbon yield was produced using $\mathrm{NaCl}$ activator. The yield of activated carbon from oil palm fronds decreased with increasing carbonization temperature of $400-600{ }^{\circ} \mathrm{C}$. This result relates to the high rate of reaction carbon and activator substances to deliver volatile components along with increasing texture characteristics of the activated carbon, which forms pores (Chen et al., 2011) and carbon burning (Saka, 2012).

Activator concentration significantly influences the

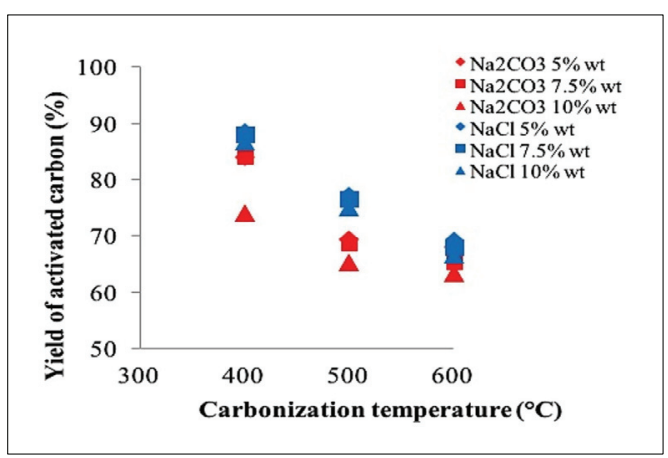

Fig. 2. Yield of activated carbon at various temperatures and concentrations. yield of the resulting carbon (Tan et al., 2008), where the amount decreases as the activator concentration increases. This phenomenon occurs because the activator will increase the release of volatile components due to dehydration reaction, which can increase carbon burning (Adinata et al., 2005).

\subsection{Moisture content}

The moisture content shows in Fig. 3 at various carbonization temperatures, activator types, and activator concentrations. The moisture content of activated carbon produced with $\mathrm{Na}_{2} \mathrm{CO}_{3}$ as activator reached $5.00-11.90 \%$. The activator of $\mathrm{NaCl}$ produced moisture content of 4.90-13.80\%. Moisturecontent decreased along with carbonization temperature due to the decreasing in the pores of activated carbon. This phenomenon results in reduced hygroscopic capability of activated carbon (Mitome et al., 2013). Moisture content in raw material lower than activated carbon, because of tar and organic materials are still inside the pore (Maulina and Anwari, 2019). Activator concentration also affects the moisture content produced. Increased water levels suggest that the activator degrades additional organic molecules during carbonization (Son et al., 2005). Fig. 3 reveals that the moisture content of the activated carbon higher with in-

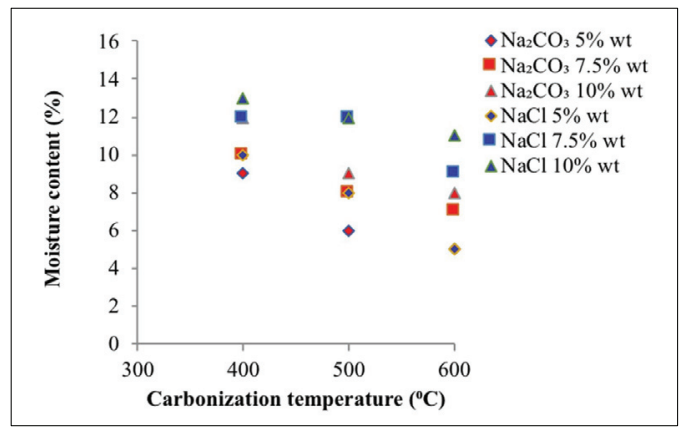

Fig. 3. Moisture content of activated carbon at various carbonization temperatures, activated types, and activator concentrations. 
Quality Comparison of Activated Carbon Produced From Oil Palm Fronds by Chemical Activation Using Sodium Carbonate versus Sodium Chloride

creasing activator concentration, promoting the dissolution of tar and organic minerals on activated carbon. Thus, the amount and depth of pores of activated carbon produced will higher with increasing activator concentration. Ultimately, this phenomenon will increase the hydroscopic characteristics to absorb water from air (Tani et al., 2014). Moisture content obtained were in accordance with the activated carbon quality standard based on SNI 06-3730-1995, which required a maximum water content of $15 \%$.

Moisture content analysis showed that sodium carbonate activators performed better than sodium chloride activators, that is, sodium carbonate activators are better than sodium chloride activators at dissolving tar and organic minerals upon impregnation and carbonization and will increase the number of pores, thus increasing water absorption from air.

\subsection{Ash content}

Fig. 4 reveals the ash content at different carbonization temperatures, activator types, and activator concentrations in activated carbon.

Fig. 4 shows that the ash content produced using $\mathrm{Na}_{2} \mathrm{CO}_{3}$ as activator reached $2.20-13.00 \%$, whereas the activator $\mathrm{NaCl}$ produced an ash content of 5.60$13.00 \%$. Ash content in charcoal as a raw material

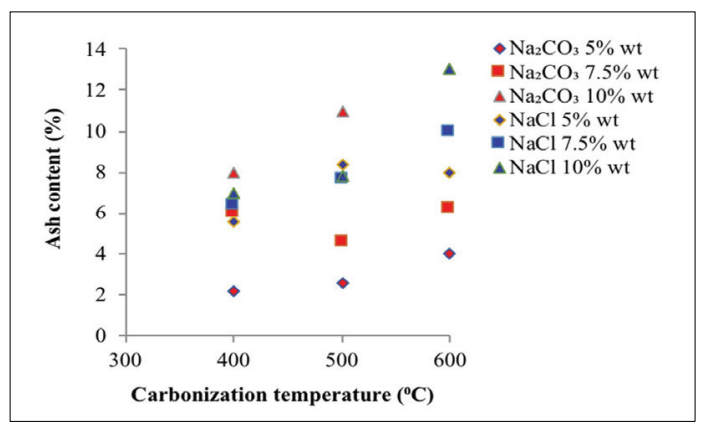

Fig. 4. Ash content of activated carbon at various carbonization temperatures, activator types, and activator concentrations. higher than activated carbon, organic materials in raw material will generate metal oxides and will increase the amount of ash content (Maulina and Anwari, 2019). The ash content of activated carbon increased with increasing carbonization temperature. This finding indicates that an increase in carbonization temperature increases the vaporization of specific volatile compounds, which are within the particles at high carbonization temperatures (Rodenas et al., 2003). In addition, carbon burning will increase the ash content on activated carbon (Saka, 2012). Ash content increased along with the high concentration of activators. The high concentration of the activator will increase the surface area of activated carbon, which will result in formation of additional pores. Increased pores formation results in additional ash production (Tani et al., 2014).

High ash content can cause environmental problems in this case related to air pollution. As a solution to this problem, ash and silica content are used as reinforcement in rubber vulcanization (Sombatsompop, et al., 2004). Fly ash generated from desalination and power plants is used to capture $\mathrm{CO}_{2}$ emitted from industries (Alhamed et al., 2015).

Ash content is determined by the quantity of silica present in raw material. More silica content results in greater ash content (Kamariya et al., 2016). Silica can cause pore blockage in activated carbon, thus reducing the surface area (Jin et al., 2012). A high activator concentration will cause the silica to dissolve in the activator, thus increasing the surface area of activated carbon. Ultimately, this reaction increases pore formation (Tani et al., 2014). The resulted ash content using $\mathrm{Na}_{2} \mathrm{CO}_{3}$ activator was lower than that obtained with $\mathrm{NaCl}$. This finding suggests that compared with $\mathrm{NaCl}, \mathrm{Na}_{2} \mathrm{CO}_{3}$ as activator can better maintain heat in carbonization, thus preventing further oxidation against organic substances, which will yield undesirable substances such as ash (Son et al., 2005). 


\subsection{Volatile matter content}

Fig. 5 shows the volatile matter content at various carbonization temperatures, types of activators, and activator concentrations in activated carbon.

Fig. 5 shows that the volatile matter contents obtained with $\mathrm{Na}_{2} \mathrm{CO}_{3}$ and $\mathrm{NaCl}$ activators reached 11.00 $-21.80 \%$ and $12.80-24.50 \%$, respectively. Generally, volatile matter of raw material still higher compare to activated carbon, because of tar and material organic (Maulina and Anwari, 2019). The volatile matter content was decreased with rising the temperature of carbonization, that is, higher carbonization temperature indicates better decomposition of non-carbon compounds in activated carbon. This result indicates the production of volatile substances and carbon burning, resulting in low volatile matter content (Chen et al., 2011; Saka, 2012).

Fig. 5 also shows that an increase in activator concentration will decrease the volatile matter content. This finding is due to the added activator, which will seep, coat, and protect the material from heat. Thus, the high concentration of activators decreases the amount of ingredients burned (Caroline et al., 2015). The addition of the activator also caused the degradation of organic material, and this condition can weaken the surface structure of activated carbon and then

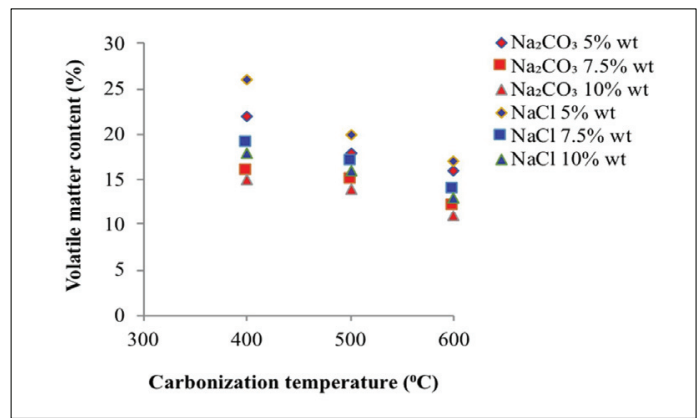

Fig. 5. Volatile matter content of activated carbon at various carbonization temperatures, types of activators, and activator concentrations. cause the release of volatile substances and development of microporous structure on activated carbon. $\mathrm{Na}_{2} \mathrm{CO}_{3}$ activators are better than $\mathrm{NaCl}$ as $\mathrm{Na}_{2} \mathrm{CO}_{3}$ activators can produce lower volatile matter content. This finding is attributed to the capability of activator $\mathrm{Na}_{2} \mathrm{CO}_{3}$ to better seep, coat, and protect the material from heat than $\mathrm{NaCl}$ activator. Thus, a result of low volatile matter content was observed.

\subsection{Fixed carbon content}

Fig. 6 reveals the fixed carbon content of activated carbon at various carbonization temperatures, types of activators, and activator concentrations.

Fig. 6 reveals that the fixed carbon contents obtained using $\mathrm{Na}_{2} \mathrm{CO}_{3}$ and $\mathrm{NaCl}$ activators totaled 65.30 $-75.30 \%$ and $58.70-74.20 \%$, respectively. The fixed carbon content of activated carbon is inversely proportional to water, ash, and volatile matter contents (Caroline et al., 2015). In general, fixed carbon content rise with higher concentration of activator. The addition of activator concentration will increase the activated carbon content as the non-carbon compounds of carbonization will be more easily dissolved with the activator, as indicated by the dense color of the activated carbon (Caroline et al., 2015). Fixed carbon of raw material lower than activated carbon, because of

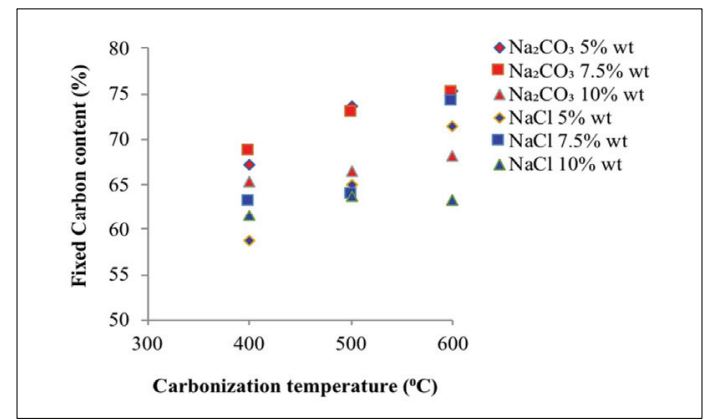

Fig. 6. Fixed carbon content of activated carbon at various carbonization temperatures, types of activators, and activator concentrations. 
Quality Comparison of Activated Carbon Produced From Oil Palm Fronds by Chemical Activation Using Sodium Carbonate versus Sodium Chloride

organic material and tar content in raw material (Maulina and Anwari, 2019)

Fig. 6 also shows that $68.60 \%$ of fixed carbon content was obtained from sodium carbonate impregnation treatment at $400{ }^{\circ} \mathrm{C}$ with different activator concentrations. This level increased at $7.50 \%$ activator concentration and decreased to $65.30 \%$ at $10 \%$ activator concentration. Impregnation treatment of $\mathrm{NaCl}$ solution at the same temperature with different activator concentrations resulted in a fixed carbon content of $63.10 \%$. This level increased at $7.50 \%$ of activator concentration and decreased to $61.60 \%$ at $10 \%$ of activator concentration. At least three factors affect the exchange in bound carbon content namely ash content, volatile matter content, and water content, of activated carbon (Tsoumis, 1991). In addition to the influence of ash and fly contents, the resulting fixed carbon content is also influenced by contents of lignocellulosic material as lignin and cellulose that could be converted to carbon atoms (Caroline et al., 2015).

\subsection{Absorption capacity of iodine}

Fig. 7 shows the adsorption capacity of iodine on activated carbon at various carbonization temperatures, types of activators, and activator concentrations. The iodine levels obtained with $\mathrm{Na}_{2} \mathrm{CO}_{3}$ and $\mathrm{NaCl}$ activa-

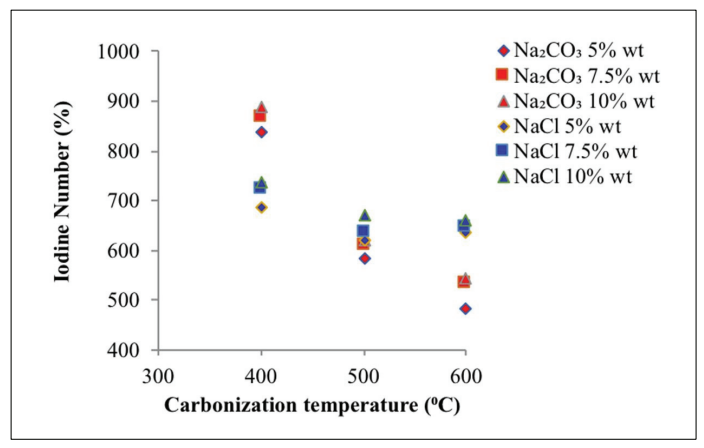

Fig. 7. Absorption capacity of iodine on activated carbon at various carbonization temperatures, type of activators, and activator concentration. tors ranged between 482.34 and $888.55 \mathrm{mg} / \mathrm{g}$ and between 621.96 and $736.19 \mathrm{mg} / \mathrm{g}$, respectively. Higher carbonization temperature indicated lower iodine absorption. This finding was attributed to two factors:breakdown of carbon surface due to the high temperature of carbonization and collapse of the wall due to carbon burning (Chen et al., 2011). Alkaline and salt activators can produce activated carbon with maximum micropores under operating conditions of less than $500{ }^{\circ} \mathrm{C}$ (Marsh and Reinoso, 2006).

The volatile compounds present in the interior of activated carbonparticles will further evaporate at high carbonization temperatures (Rodenas et al., 2003). This reaction triggers carbon burning, which can increase ash content on activated carbon (Saka, 2012).

Increasing activator concentration increased the absorption power of iodine. This reaction is due to reduced tar levels observed along with increased activator concentration at the time of immersion. Thus, the number of pores that were present in the activated carbon increased, thus increasing absorption (Son et al., 2005). This finding is associated with a wide reaction between the activator substance and the carbon surface (Deng et al., 2010) resulting in an increased release of $\mathrm{CO}_{2}$ and $\mathrm{CO}$ gases, which triggered an increase in pore formation (Mitome et al., 2013).

\subsection{Morphological analysis surfaces of activated carbon}

The SEM analysis of active surface carbon shows on Figs. 8 and 9.

During carbonization, $\mathrm{Na}_{2} \mathrm{CO}_{3}$ decomposes from a metal compound of sodium to form carbon. The sodium metal atoms formed during activation and carbonization can enter carbon structures; this condition can expand the pores and create new porosity. $\mathrm{Na}_{2} \mathrm{CO}_{3}$ can be decomposed with carbon at above $400{ }^{\circ} \mathrm{C}$. Thus, carbon is replace as $\mathrm{CO}$ and increases the surface area and pore volume. At high temperatures, 


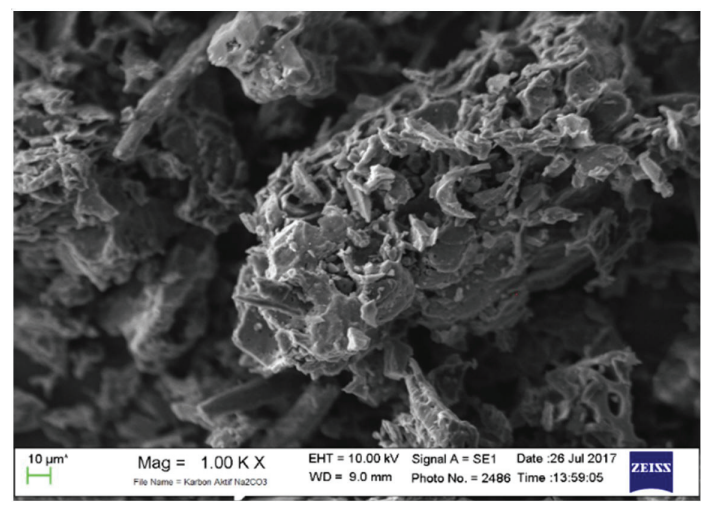

Fig. 8. SEM analysis of activated carbon with $\mathrm{Na}_{2} \mathrm{CO}_{3}$ activator at $1000 \mathrm{x}$ magnifications.

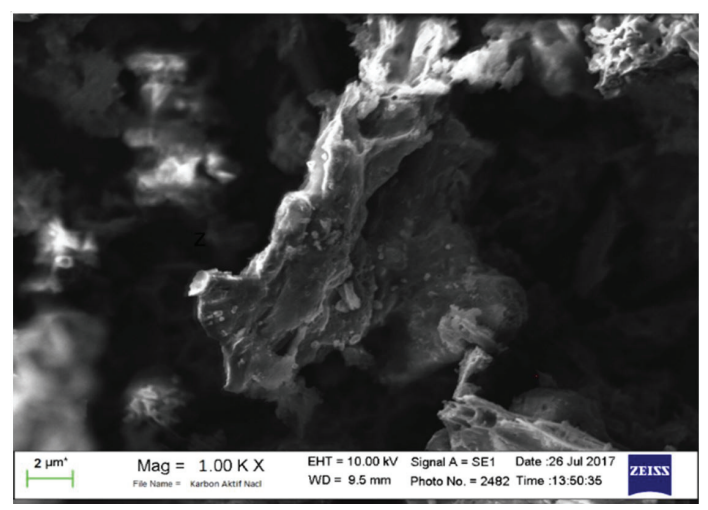

Fig. 9. SEM analysis of activated carbon with $\mathrm{NaCl}$ activator at $1000 \mathrm{x}$ magnifications.

pores form, and the mesoporous volume increases, but the absorption capacity of iodine decreases (Jin et al., 2012).

As shown in Figs. 8 and 9, more pores formed with greater pore cavity depth after using $\mathrm{Na}_{2} \mathrm{CO}_{3^{-}}$activated carbons compared with $\mathrm{NaCl}$-activated carbons. In addition, the $\mathrm{Na}_{2} \mathrm{CO}_{3}$ activator showed better iodine absorption $(888.51 \mathrm{mg} / \mathrm{g})$ compared with the $\mathrm{NaCl}$ activator $(736.19 \mathrm{mg} / \mathrm{g})$.

\subsection{FTIR analysis of activated carbon}

This study used the absorption method for spectroscopic observation; this method is based on differ-

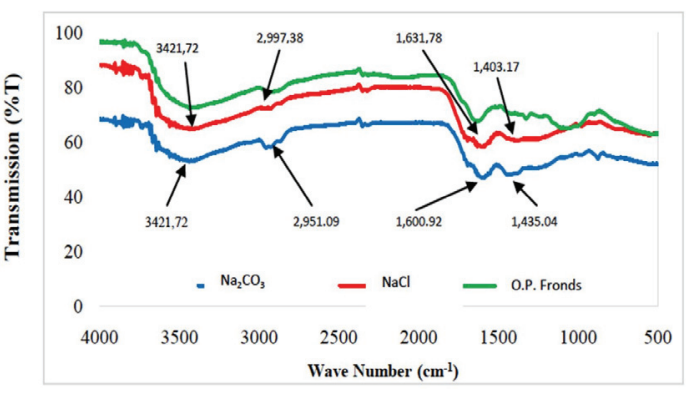

Fig. 10. FTIR analysis of oil palm fronds, $\mathrm{Na}_{2} \mathrm{CO}_{3}$ and $\mathrm{NaCl}$ activated carbons.

ences in the absorption of infrared radiation. Fig. 10 present the results of FTIR analysis on the resulting activated carbon.

The absorption peak occurred at $3421.72 \mathrm{~cm}^{-1}$, which corresponds to by oil palm fronds and $\mathrm{Na}_{2} \mathrm{CO}_{3}$ and $\mathrm{NaCl}$-activated carbons. The absorption peaks at $3500-3200 \mathrm{~cm}^{-1}$ (indicating to $\mathrm{O}-\mathrm{H}$ spread) indicate the existence of hydroxyl (O-H) functional group. In the FTIR wave spectrum of activated carbon with $\mathrm{Na}_{2} \mathrm{CO}_{3}$ and $\mathrm{NaCl}$ activators, an absorption peak appeared with wave numbers of 1631.78 and 1600.92 $\mathrm{cm}^{-1}$, respectively. The absorption peaks occurring in the range of $1820-1600 \mathrm{~cm}^{-1}$ indicate the presence of $\mathrm{C}=\mathrm{O}$ groups, which are typical groups of activated carbon. The peaks also showed that oil palm fronds originated form carbon-active substances (Kamariya et al., 2016).

Activation of carbon using $\mathrm{Na}_{2} \mathrm{CO}_{3}$ and $\mathrm{NaCl}$ also formed a $\mathrm{C}=\mathrm{C}$ bond. This result was proven by the observation of spectra at wave numbers of $1,435.04$ and $1,403.17 \mathrm{~cm}^{-1}$. The absorption peaks at $1500-1400$ $\mathrm{cm}^{-1}$ referring the presence of the $\mathrm{C}=\mathrm{C}$ group. Absorption peaks with wave numbers of 2951.09 and 299.73 $\mathrm{cm}^{-1}$ indicate the presence of C-H groups (3000-2850 $\mathrm{cm}^{-1}$ ) and alkane compounds, respectively (Mitome et al., 2013). Four types of functional groups, namely, $\mathrm{C}=\mathrm{O}, \mathrm{C}=\mathrm{C}, \mathrm{C}-\mathrm{C}$, and $\mathrm{C}-\mathrm{H}$ groups, are contained in palm oil activated carbonyl. 
Quality Comparison of Activated Carbon Produced From Oil Palm Fronds by Chemical Activation Using Sodium Carbonate versus Sodium Chloride

\section{CONCLUSION}

The depth of the pore cavity is greater by using sodium carbonate activator than sodium chloride. This is also proved by Iodine number using sodium carbonate activator higher than sodium chloride activator in the activated carbon produced at temperature of 400 ${ }^{\circ} \mathrm{C}$. $\mathrm{Na}_{2} \mathrm{CO}_{3}$ activator showed better iodine absorption $(888.51 \mathrm{mg} / \mathrm{g})$ compared to $\mathrm{NaCl}$ activator (736.19 $\mathrm{mg} / \mathrm{g}) . \mathrm{Na}_{2} \mathrm{CO}_{3}$ has fulfilled the requirement of $\mathrm{SNI}$ 06-3730-1995.

\section{ACKNOWLEDGMENT}

The authors wholeheartedly appreciate to Universitas Sumatera Utara.

\section{REFERENCES}

Adinata, D., Daud, W.M.A.W., Aroua, M.K. 2005. Preparation and characterization of activated carbon from palm shell by chemical activation with $\mathrm{K}_{2} \mathrm{CO}_{3}$. Journal of Bioresource Technology 98(1): 145-149. Alhamed, Y.A., Rather, S.U., El-Shazly, A.H., Zaman, S.F., Daous, M.A., Al-Zahrani, A.A. 2015. Preparation of activated carbon from fly ash and its application for $\mathrm{CO}_{2}$ capture. Korean Journal of Chemical Engineering 32(4): 723-730.

Caroline, S., Adebayo, M.A., Lima, E.C., Cataluna, R., Thue, P.S., Prola, L.D.T., Puchana-Rosero, M.J., Machado, F.M., Pavan, F.A., Dotto, G.L. 2015. Microwave-assisted Activated Carbon from Cocoa Shell Adsorbent for Removal of Sodium Diclofenac and Nimesulide from Aqueous Effluents. Journal of Hazardous Materials 289: 18-27.

Chen, Y., Huang, B., Huang, M., Cai, B. 2011. On the preparation and characterization of activated carbon from mangosteen shell. Journal of the Taiwan Institute of Chemical Engineers 42(5):
837-842.

Deng, H., Li, G., Yang, H., Tang, J., Tang, J. 2010. Preparation of activated carbons from cotton stalk by microwave assisted $\mathrm{KOH}$ and $\mathrm{K}_{2} \mathrm{CO}_{3}$ Activation. Chemical Engineering Journal 163(3): 373-381.

Hamchara, P., Chanjula, P., Cherdthong A., Wanapat, M. 2018. Digestibility, ruminal, fermentation, and nitrogen balance with various feeding levels of oil palm fronds treated with lentinus sajor-caju in goats. Asian-Australasian Journal of Animal Sciences 31(10): 1619-1626.

Hong, LS., Ibrahim, D., Omar, IC. 2012. Oil palm frond for the production of bioethanol. International Journal of Biochemistry and Biotechnology 1(1): 7-11.

Irvan, Trisakti, B., Maulina S., Daimon, H. 2018. Production of biogas from palm oil mill effluent: from laboratory scale to pilot scale. Rasayan Journal of Chemistry 11(1): 378-385.

Jin, X.J., Yu, Z.M., Wu, Y. 2012. Preparation of activated carbon from lignin obtained by straw pulping by $\mathrm{KOH}$ and $\mathrm{K}_{2} \mathrm{CO}_{3}$ chemical activation. Cellulose Chemistry and Technology 46(1-2): 7985.

Kamariya, S., Pandya, J., Charola, S. 2016. Preparation and characterization of activated carbon from agricultural waste, peanut shell by chemical activation. International Journal of Trend in Research and Development 3(3): 138-141.

Marsh, H., Reinoso, F.R. 2006. Activated carbon. Elsevier Science and Technology Books. Netherlands, Holland.

Maulina, S., Nurtahara, Fakhradila. 2018. Palm midrib pyrolysis to produce phenol in liquid smoke. Jurnal Teknik Kimia USU 7(2): 12-16.

Maulina, S., Anwari, F.N. 2019. Comparing characteristic of charcoal and activated carbon from oil palm fronds. IOP Conf. Series: Earth and Environmental Science 305: 012059. 
Mitome, T., Uchida, Y., Egashira, Y., Hayashi, K., Nishiura, A., Nishiyama, N. 2013. Characterization and properties of activated carbon prepared from tamarind seeds by $\mathrm{KOH}$ activation for $\mathrm{Fe}$ (III) adsorption from aqueous solution. Journal of Colloids and Surfaces A: Physicochemical and Engineering Aspects 424(1): 89-95.

Pambayun, G.S., Yulianto, R.Y.E., Rachimoellah, M., Putri, E.M.M. 2013. Pembuatan karbon aktif dari arang tempurung kelapa dengan aktivator $\mathrm{ZnCl}_{2}$ dan $\mathrm{Na}_{2} \mathrm{CO}_{3}$ sebagai absorben untuk mengurangi kadar fenol dalam air limbah. Jurnal Teknik POMITS 2(1): 1-5.

Prabuningrum, D.S., Massijaya, M.Y., Hadi, Y.S., Abdillah, I.B. 2020. Physical-mechanical properties of laminated board made from oil palm trunk (Elaeis guineensis Jacq.) waste with various lamina compositions and densifications. Journal of the Korean Wood Science and Technology 48(2): 196-205.

Rahman, N., Valery, G., Njoya, D., Wahabou, A., Bacaoui, A., Yaacoubi, A. 2018. Development of porosity of low cost activated carbon from postconsumer plastics and lignocellulosic waste materials using physico-chemical activation. Global Journal of Science Frontier Research 18(2): 21-29.

Ramdja, A.F., Halim, M., Handi, J. 2008. Pembuatan karbon aktif dari pelepah kelapa (Cocus nucifera). Jurnal Teknik Kimia 15(2): 1-8.

Rodenas, M.A., Amoros, D.C., Solano, A.L. 2003. adsorption. Carbon 41(2): 267-275.

Saka, C. 2012. BET, TG-DTG, FT-IR, SEM, Iodine number analysis and preparation of activated carbon from acorn sheel by chemical activation with $\mathrm{ZnCl}_{2}$. Journal of Analytical and Applied Pyrolysis 95: 21-24.

Sombatsompop, N., Thongsang, S., Markpin, T., Wimolmala, E. 2004. Fly ash particles and precipitated silica as fillers in rubbers. I. Untreated fillers in natural rubber and styrene-butadiene rubber compounds. Journal of Applied Polymer Science 93(5): 2119-2130.

Son, S.J., Choi, J.S., Choo, K.Y., Song, S.D., Vijayalakshmi, S., Kim, T.H. 2005. Development of carbon dioxide adsorbents using carbon materials prepared from coconut shell. Korean Journal of Chemical Engineering 22(2): 291-297.

Tan, I.A.W., Ahmad, A.L., Hameed, B.H. 2008. Preparation of activated carbon from coconut husk: optimization study on removal of 2,4,6-trichlorophenol using response surface methodology. Journal of Hazardous Material 153(1): 709-717.

Tani, D., Setiaji, B., Trisunaryanti, W., Syoufian, A. 2014. Effect of activation time on chemical structure and quality of coconut shell avtivated carbon. Asian Journal Science Technology 5(9): 553-556 Tsoumis, G. 1991. Science and technology of wood: structure, properties, utilization. Van Nostrand Reinhold. New York, USA. 